\title{
Southern Farmers' Attitudes and Opinions about Federal Conservation Programs and the 2007 Farm Bill1
}

\author{
Michele C. Marra, Rodney L. Clouser, James L. Novak, and Nathan B. Smith²
}

\section{Introduction}

U.S. Department of Agriculture officials have held "listening sessions" across the country to try to get a feeling for the public's attitudes, opinions, and suggestions on various topics relating to the 2007 Farm Bill. Other agricultural and environmental groups have outlined their position on some of the programs likely to be considered during the Farm Bill debate. The USDA Cooperative State Research and Extension Service (CSREES) in cooperation with the Farm Foundation and the National Agricultural Statistics Service (NASS) conducted a direct mail survey of farmers to ascertain their attitudes and opinions on various topics to be considered in the Farm Bill debate. This fact sheet draws from the results of that national survey to report on southern farmers' attitudes and opinions about present and future conservation programs and goals (Lubben, et al., 2006). The states in the southern region that participated in the 2006 Farm Bill Survey are Alabama, Florida, Georgia, North Carolina, and Texas.

\section{Federal Assistance with Environmental Goals}

The first question about conservation in the survey asked farmers to give their desired level of federal assistance in meeting national environmental goals. The environmental goals in the survey question were improvements in water quality, soil erosion, air quality, wildlife habitat, open space protection, animal waste management, carbon sequestration, and biodiversity maintenance. Southern farmers' responses are reported in Table 1.

\section{Water Quality and Soil Erosion Improvements}

An average of 8 percent of southern farmers surveyed desired no assistance with improving water quality, with a range from 2 percent in Georgia to 10 percent in Texas. An overwhelming majority (66 percent of respondents) desired both technical and financial assistance (ranged from 63 percent in Texas to 70 percent in Alabama) and 7 percent reported that they didn't know.

1. This is EDIS document FE682, a publication of the Food and Resource Economics Department, Florida Cooperative Extension Service, Institute of Food and Agricultural Sciences, University of Florida, Gainesville, FL. Published February 2007. Please visit the EDIS website at http://edis.ifas.ufl.edu.

2. Michele C. Marra, Professor and Specialist, Agricultural and Resource Economics Department, North Carolina State University, Raleigh, NC; Rodney L. Clouser, Professor and Specialist, Food and Resource Economics Department, Florida Cooperative Extension Service, Institute of Food and Agricultural Sciences, University of Florida, Gainesville, FL; .James L. Novak, Professor and Specialist, Agricultural Economics and Rural Sociology Department, Auburn University, Auburn, AL; and Nathan B. Smith, Professor and Specialist, Agricultural and Applied Economics Department, University of Georgia, Tifton, GA.

The Institute of Food and Agricultural Sciences (IFAS) is an Equal Opportunity Institution authorized to provide research, educational information and other services only to individuals and institutions that function with non-discrimination with respect to race, creed, color, religion, age, disability, sex, sexual orientation, marital status, national origin, political opinions or affiliations. U.S. Department of Agriculture, Cooperative Extension Service, University of Florida, IFAS, Florida A. \& M. University Cooperative Extension Program, and Boards of County Commissioners Cooperating. Larry Arrington, Dean 
A little more than half of Florida farmers desired both types of assistance for soil erosion improvements, while 73 percent of Alabama farmers desired both types of assistance. The percentages of respondents reporting that they wanted no assistance or that they didn't know were about the same for both water quality improvements and soil erosion improvement. By state, Alabama farmers showed the largest percentage of respondents desiring both technical and financial assistance for water quality and soil erosion improvement. On average, improvements in water quality and soil erosion control were the goals ranked highest among southern farmers in terms of their desire for both technical and financial assistance.

\section{Air Quality and Wildlife Habitat Improvements}

A smaller percentage (49 percent) of southern farmers reported wanting both technical and financial assistance with air quality and wildlife habitat improvements compared with improvements in water quality and soil erosion protection, with a range of 45 percent in Texas to 59 percent in Alabama. Nine percent of southern farmers reported wanting no assistance with improving air quality (ranged from 6 percent in Georgia to 11 percent in Texas) and 14 percent reported wanting no assistance with improving wildlife habitat, with a range of 8 percent in Alabama and Georgia to 18 percent in Texas. The higher percentage of southern farmers needing no assistance with improvements in wildlife habitat may be because it is profitable for farmers to improve wildlife habitat in many areas of the South. Many hunters are willing to pay a premium for hunting on land that includes an improved wildlife habitat, which improves farmers' bottom lines and the environment. These private incentives seem to be enough for some farmers to improve wildlife habitat on their own. Another explanation for relatively low support for technical and financial assistance is that producers may not perceive air quality and wildlife habitat improvement as significant problems in their specific locales.

\section{Improved Animal Waste Management}

Only 40 percent of southern farmers report wanting both technical and financial assistance with animal waste management. However, 55 percent of North Carolina farmers reported a desire for both types of assistance while only 35 percent of Texas farmers reported a desire for both types of assistance. North Carolina was ranked second in hog and turkey production and fourth in broiler production in the nation in 2005 (USDA, NASS, 2006). Texas, on the other hand, while having a large and robust livestock industry (ranked first in cattle and sheep/lamb production in 2005), does not face as much of a problem with livestock waste management because there is more space in which to deal with the waste and the large livestock operations are not as close to urban areas as they are in some of the other southern states (USDA, NASS, 2006).

\section{Open Space Protection, Carbon Sequestration, and Biodiversity Management Improvements}

These three goals have some features in common. First, they are goals that have a longer time horizon than the goals previously discussed. Second, it appears that a larger percentage of southern farmers reported they don't know what type of assistance they need, or that they don't know enough about the environmental goal to have an opinion. For each goal, the percentage of southern farmers reporting "Don't know" is 20 percent or greater. It has been shown in several economic studies that we as a nation value open spaces, especially within a short drive of urban areas (McConnell and Walls, 2005). Thus one of the environmental goals southern farmers were asked about in the survey was what type of assistance was desired from federal sources to protect these open spaces. An average of 37 percent of southern farmers reported a desire for both technical and financial assistance for this goal. Another 28 percent reported a desire for technical assistance only and 16 percent reported needing no assistance.

Carbon sequestration involves using carbon sinks to capture the carbon dioxide produced by modern society so that it will not add to the greenhouse effect or global climate change. Several methods pertaining to agriculture are involved. First, increasing the 
amount of plant material on the earth's surface, especially young and growing forests, so that some of the carbon dioxide produced can be stored (sequestered) in the plant material. Second, carbon dioxide can be sequestered in soils by increasing soil organic matter. This is accomplished by using conservation tillage practices, cover crops, and crop rotation (Wikipedia, 2006). Almost 40 percent of southern farmers reported that they don't know what type of assistance, if any, they desired to improve carbon sequestration, with a range of 34 percent in Alabama to 40 percent in North Carolina and Texas. It is likely that some of these responses are caused by uncertainty about the meaning of carbon sequestration and what farmers can do about it. Only 24 percent of southern farmers reported wanting both technical and financial assistance for this environmental goal, with a range of 20 percent in Texas to 31 percent in Florida.

Similar to carbon sequestration, biodiversity maintenance seems to have been less well understood by southern farmers, with 33 percent of them reporting that they don't know what kind of assistance is needed. The United Nations Food and Agriculture Organization (FAO) states the benefits of biodiversity. "A wide range of species provides many thousands of products through agriculture and from the harvest of natural populations .... A diverse range of organisms contributes to the resilience of agricultural and natural ecosystems, their capacity to recover from environmental stress and their ability to evolve" (FAO, 2006). Only 30 percent reported wanting technical and financial assistance with this goal, with a range of 26 percent in Texas to 37 percent in Florida and North Carolina.

\section{Southern Farmers' Attitudes about Specific Conservation Programs}

\section{State Conservation Block Grants}

State conservation block grants are being proposed to allow more flexibility so that states can decide how the money is spent for agricultural conservation purposes. This program would be similar to the community development block grants program operated by the U.S. Department of Housing and Urban Development. Table 2 reveals that more than half of southern farmers agree or strongly agree that this program would be a good idea, and in general more than twice as many agree as disagree with the proposed program concept. The only exception is Alabama where 45 percent of farmers agree and 29 percent disagree with the program.

\section{Conservation Reserve Program}

Farmers were asked to give their opinions on several funding concepts for the Conservation Reserve Program (CRP). This is an existing program that allows farmers to bid land into retirement based on an environmental benefits score. The contracts are from 10 to 15 years, and in return farmers receive an annual rental payment (USDA, FSA, 2006). Current debate centers around in what form the CRP will continue into the future, including whether or not it should be eliminated. Table 3 reveals that around 35 to 40 percent of southern farmers think that all land coming out of the program after the initial contract has expired should be allowed to be re-bid into the program. This is the current rule. About one-fourth of southern farmers think only land with high environmental benefits scores should be able to be re-enrolled. Less than 20 percent of farmers in the South believe the CRP should be restricted to environmentally sensitive lands, and another 21 percent believe the program should be eliminated.

\section{Conservation Security Program}

The Conservation Security Program (CSP) pays farmers who engage in conservation practices on working farmland. It is a relatively new program that has been implemented incrementally by adding new watersheds to the list of eligible land each year. Table 4 reveals that a little over half of southern farmers think the program allocation mechanism should remain the same, a little less than one-third of southern farmers think the CSP should be implemented nationwide instead of by watershed, and about one-fourth think the CSP program should be eliminated.

\section{Summary and Conclusion}

With the exception of carbon sequestration and biodiversity maintenance goals, most southern farmers report that they desire technical and financial 
assistance programs to meet environmental goals. In the cases of carbon sequestration and biodiversity maintenance, more farmers don't know what type of assistance they need, if any, than desire technical and financial assistance. This may be because there is more uncertainty among southern farmers about what these two environmental goals mean and what tools are available to farmers to improve them. By a margin of about two to one, farmers in the South agree that a Federal program of state conservation block grants would be a good idea. About one-fifth to one-fourth of southern farmers think the CRP and CSP programs should be eliminated. About 40 percent think the current CRP program should be continued with the current re-enrollment provisions, and about half think the CSP program should be maintained as is.

The information contained in this report should help policy makers make decisions that take the desires of farmers into consideration. This information should also be of use to state Extension specialists and county agents in the southern region, in that it shows some areas where more farmer education might be beneficial.

\section{References}

Food and Agriculture Organization. 2006.

Biodiversity. FAO, United Nations, New York, NY.

http://www.fao.org/biodiversity/

index.asp?lang=en. Accessed online 9/6/06.

Lubben, B., N. Bills, J. Johnson, and J. Novak. 2006. The 2007 Farm Bill: U.S. Producer

Preferences for Agricultural, Food, and Public

Policy. CSREES National Public Policy

Education Committee, and Farm Foundation, University of Nebraska, Lincoln, NB.

McConnell, V. and M. Walls. 2005. The Value of Open Space: Evidence from Studies of Non-Market Benefits. Resources for the Future, Washington D.C.

http://www.rff.org/rff/Documents/RFFREPORT-Open\%20Spaces.pdf. Accessed online 8/31/06.
USDA, Farm Service Agency, 2006.

Conservation Reserve Program - Sign-up 33.

FSA, USDA, Washington, D.C. http://www.fsa.usda.gov/dafp/cepd/crp.htm. Accessed online 9/5/06.

USDA, National Agricultural Statistics Service, Agricultural Statistics Board, 2006. Meat Animals Production, Disposition, and Income 2005 Summary [Mt AN 1-1 (06)]. USGPO, Washington, D.C. (April). http://usda.mannlib.cornell.edu/MannUsda/ viewDocumentInfo.do?documentID=1101. Accessed online 9/5/06.

Wikipedia. Carbon Sequestration. http://en.wikipedia.org/wiki/ Carbon_sequestration\#Forests_2. Accessed online 9/7/06. 
Table 1. Southern farmers' desired assistance from the federal government with environmental goals.

\begin{tabular}{|c|c|c|c|c|}
\hline State / Region & $\begin{array}{c}\text { No } \\
\text { Assistance }\end{array}$ & $\begin{array}{l}\text { Technical } \\
\text { Assistance }\end{array}$ & $\begin{array}{l}\text { Technical/ } \\
\text { Financial } \\
\text { Assistance }\end{array}$ & Don't Know \\
\hline & \multicolumn{4}{|c|}{$\%$ of Respondents } \\
\hline & \multicolumn{4}{|c|}{ Water Quality } \\
\hline Alabama & 7 & 17 & 70 & 6 \\
\hline Florida & 8 & 21 & 64 & 6 \\
\hline Georgia & 2 & 23 & 68 & 7 \\
\hline North Carolina & 6 & 17 & 67 & 9 \\
\hline Texas & 10 & 20 & 63 & 7 \\
\hline \multirow[t]{2}{*}{ South } & 8 & 20 & 66 & 7 \\
\hline & \multicolumn{4}{|c|}{ Soil Erosion } \\
\hline Alabama & 6 & 18 & 73 & 4 \\
\hline Florida & 7 & 31 & 54 & 8 \\
\hline Georgia & 2 & 29 & 64 & 5 \\
\hline North Carolina & 7 & 24 & 64 & 6 \\
\hline Texas & 6 & 21 & 68 & 6 \\
\hline \multirow[t]{2}{*}{ South } & 6 & 23 & 66 & 6 \\
\hline & \multicolumn{4}{|c|}{ Air Quality } \\
\hline Alabama & 8 & 24 & 59 & 10 \\
\hline Florida & 10 & 28 & 53 & 11 \\
\hline Georgia & 6 & 33 & 53 & 8 \\
\hline North Carolina & 10 & 23 & 55 & 12 \\
\hline Texas & 11 & 33 & 45 & 12 \\
\hline \multirow[t]{2}{*}{ South } & 9 & 30 & 49 & 11 \\
\hline & \multicolumn{4}{|c|}{ Wildlife Habitat } \\
\hline Alabama & 8 & 33 & 52 & 7 \\
\hline Florida & 10 & 24 & 58 & 8 \\
\hline Georgia & 8 & 31 & 55 & 6 \\
\hline North Carolina & 12 & 28 & 51 & 9 \\
\hline Texas & 18 & 29 & 44 & 10 \\
\hline South & 14 & 28 & 49 & 9 \\
\hline
\end{tabular}


Table 1. Southern farmers' desired assistance from the federal government with environmental goals.

\begin{tabular}{|c|c|c|c|c|}
\hline State / Region & $\begin{array}{c}\text { No } \\
\text { Assistance }\end{array}$ & $\begin{array}{l}\text { Technical } \\
\text { Assistance }\end{array}$ & $\begin{array}{l}\text { Technical / } \\
\text { Financial } \\
\text { Assistance }\end{array}$ & Don't Know \\
\hline & \multicolumn{4}{|c|}{$\%$ of Respondents } \\
\hline & \multicolumn{4}{|c|}{ Animal Waste Management } \\
\hline Alabama & 11 & 29 & 47 & 12 \\
\hline Florida & 12 & 33 & 38 & 16 \\
\hline Georgia & 11 & 34 & 41 & 15 \\
\hline North Carolina & 9 & 25 & 55 & 11 \\
\hline Texas & 16 & 33 & 35 & 16 \\
\hline \multirow[t]{2}{*}{ South } & 14 & 32 & 40 & 15 \\
\hline & \multicolumn{4}{|c|}{ Open Space Protection } \\
\hline Alabama & 12 & 31 & 36 & 21 \\
\hline Florida & 17 & 25 & 42 & 17 \\
\hline Georgia & 10 & 33 & 41 & 17 \\
\hline North Carolina & 15 & 25 & 44 & 16 \\
\hline Texas & 19 & 27 & 33 & 22 \\
\hline \multirow[t]{2}{*}{ South } & 16 & 28 & 37 & 20 \\
\hline & \multicolumn{4}{|c|}{ Carbon Sequestration } \\
\hline Alabama & 10 & 27 & 30 & 34 \\
\hline Florida & 10 & 24 & 31 & 37 \\
\hline Georgia & 8 & 27 & 27 & 37 \\
\hline North Carolina & 8 & 21 & 31 & 40 \\
\hline Texas & 15 & 25 & 20 & 40 \\
\hline \multirow[t]{2}{*}{ South } & 12 & 25 & 24 & 39 \\
\hline & \multicolumn{4}{|c|}{ Biodiversity Maintenance } \\
\hline Alabama & 9 & 28 & 35 & 28 \\
\hline Florida & 10 & 26 & 37 & 27 \\
\hline Georgia & 9 & 26 & 29 & 35 \\
\hline North Carolina & 8 & 21 & 37 & 34 \\
\hline Texas & 14 & 25 & 26 & 35 \\
\hline South & 12 & 25 & 30 & 33 \\
\hline
\end{tabular}


Table 2. Southern farmers' attitudes about a federal program of state conservation block grants.

\begin{tabular}{|c|c|c|c|c|c|c|}
\hline State / Region & $\begin{array}{l}\text { Strongly } \\
\text { Disagree }\end{array}$ & Disagree & Neutral & Agree & $\begin{array}{c}\text { Strongly } \\
\text { Agree }\end{array}$ & $\begin{array}{l}\text { No Opinion } \\
\text { Don't Know }\end{array}$ \\
\hline & \multicolumn{6}{|c|}{$\%$ of Respondents } \\
\hline Alabama & 17 & 12 & 18 & 27 & 18 & 9 \\
\hline Florida & 15 & 9 & 12 & 26 & 29 & 10 \\
\hline Georgia & 8 & 8 & 19 & 34 & 23 & 10 \\
\hline North Carolina & 9 & 8 & 16 & 33 & 19 & 15 \\
\hline Texas & 12 & 6 & 14 & 32 & 23 & 12 \\
\hline \multirow[t]{2}{*}{ South } & 12 & 8 & 15 & 31 & 23 & 12 \\
\hline & & $\%$ Disagree & & & $\%$ Agree & \\
\hline Alabama & & 29 & & & 45 & \\
\hline Florida & & 24 & & & 55 & \\
\hline Georgia & & 16 & & & 57 & \\
\hline North Carolina & & 17 & & & 52 & \\
\hline Texas & & 18 & & & 55 & \\
\hline South & & 20 & & & 54 & \\
\hline
\end{tabular}

Table 3. Southern farmers' attitudes about the future of the conservation reserve program.

\begin{tabular}{llccc|}
\hline \hline State / Region & $\begin{array}{c}\text { Re-Bid Expiring } \\
\text { Contracts }\end{array}$ & $\begin{array}{c}\text { Re-Enroll High } \\
\text { Ranking Contracts }\end{array}$ & $\begin{array}{c}\text { Restrict CRP to } \\
\text { Environmentally } \\
\text { Sensitive Lands }\end{array}$ & Eliminate CRP \\
\hline Alabama & 36 & 26 & 17 & 21 \\
Florida & 35 & 28 & 10 & 27 \\
Georgia & 41 & 29 & 13 & 16 \\
North Carolina & 38 & 28 & 16 & 18 \\
Texas & 36 & 22 & 19 & 23 \\
South & $\mathbf{3 7}$ & $\mathbf{2 5}$ & $\mathbf{1 7}$ & $\mathbf{2 1}$ \\
\hline \hline
\end{tabular}


Table 4. Southern farmers' attitudes about the future of the conservation security program.

\begin{tabular}{|lccc|}
\hline \hline State / Region & $\begin{array}{c}\text { Implement CSP } \\
\text { by Watershed }\end{array}$ & $\begin{array}{c}\text { Implement CSP } \\
\text { Nationwide }\end{array}$ & Eliminate CSP \\
\cline { 2 - 4 } Alabama & 58 & 22 & 20 \\
Florida & 47 & 24 & 28 \\
Georgia & 55 & 26 & 19 \\
North Carolina & 56 & 23 & 21 \\
Texas & 52 & 23 & 27 \\
South & 53 & 23 & 25 \\
\hline \hline
\end{tabular}

